\title{
TAKING ADVANTAGE OF INDUSTRIAL HERITAGE FOR THE NEEDS OF TOURISM IN THE SILESIAN PROVINCE
}

\author{
A. Przybyłka \\ Katedra Polityki Spotecznej i Gospodarczej \\ Uniwersytet Ekonomiczny w Katowicach, Polska
}

\begin{abstract}
Silesian province is constantly associated with an industrial region. However, in the last years a lot of industrial plants have finished or limited their production. Extraction of coal that is still a symbol of the region, is being limited over the last years. Moreover, there are still numerous postindustrial sites which have not been in a production process for many years. It gives an opportunity to use this industrial heritage for the needs of industrial tourism. In this way attractiveness of the region increases, and it makes possible usage and protection of the sites instead of their slow destruction. This article shows how industrial heritage is used for the development and promotion of the Silesian province.
\end{abstract}

Key words: industrial heritage, industrial tourism, technological monuments.

Industrial heritage that is a part of cultural heritage "writes down" the fate of civilization especially taking into account technical and technological processes.

It is irreversibly connected with the fate of settlers of the particular area, their customs, folk traditions, costumes and religion.

Hence the history of industry is "illustrated" in the material and spacious sphere structures connected with the landscape as well as antique machines and technological processes [5].

Industrial heritage includes antiques from the building and technological industries. The industrial sites are connected with the process of production, such as: coal mines, ironworks, industrial buildings connected with processing industry, as well as transport ( for example, railways with their infrastructure ).

Along with the industrial equipment we can also include machines and storage facilities [8]. According to Polish solutions, protection includes:

- Stationary technical sites being in particular technical objects, first of all coal mines, steelworks, power stations and factories.

- Movable historical sites being in particular products of technology and first of all devices, means of transport as well as machines and tools testifying about material culture specific for old and modern forms of economies, showing the level of science and the development of civilization [9].

The main aim of industrial tourism, as well as industrial heritage, is to present its heritage, and it should also bring benefits for the whole country.

However, convertion of the cultural heritage object to meet the needs of tourism is a result of a dialogue and cooperation between institutional and scientific institutions. Hence it leads to activities directed to scientific, technical, organizational and legal support [4].

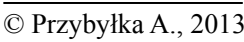


Silesian province is still one of the most industrial areas in Poland. It is located in the South part of Poland. Because of the ideal location of the province, it makes for convenient usage of the European railroad system.

Silesian province is also the biggest agglomeration of historical industrial sites in Poland. Without any doubts the industrial sights are the largest form of income in the region. They underline its character and define its cultural identity. Their originality makes them an integral part of the European cultural heritage. In the Silesian province the most industrial sites are connected with mining and metallurgy. There are numerous cultural assets connected with coking industry, chemical industry, energetics and railway. It is conditioned by the history of the region, where for many centuries manufacturing was run. Post-industrial sites of the region first appeared as a result of exploitation of mineral coal, ores, natural resources and backfilling sand. The following minerals can be found in the historic area of Upper Silesia, connected with its economic development as well as industrial heritage:

- silver and lead, had been used in the industry and craft, for many centuries silver had also been used as a currency. The first recorded history concerning mining, silver ores and lead in the region come from the $12^{\text {th }}$ and the 13 th centuries [10]; in the $15^{\text {th }}$ century, because of depletion of natural resources, mining in the area of Bytom started falling.

- zinc - abundant in galman ores out of which silver and lead were obtained; adding galman ore to melted copper increased its hardness, making it possible to obtain bronze or brass. The discovery of rich galman ores in the area of Tarnowskie Góry stimulated the ores mining in this region. In 1704, George Giza and his successors were given the prerogatives for digging and selling galman ores in the Silesia region. The opening up of zinc sites caused a further development of mining industry. Jan Rugberg, a civil servant of prince of Pszczyna, while on a vocational training in England, learned how to produce metallic brass. After his return, in Wesoła near Pszczyna, he built a zinc site which produced this new metal. The second site was set up in Królewska Huta ( Chorzów ) in 1805 - 1809, where they improved the production method. By the end of the $20^{\text {th }}$ century extraction and production of zinc and lead was limited because of ecological devastation of the extraction sites and too many health-related dangers.

- Iron ores - the first mentions in the Silesia region come from the period of Sorbian culture ( $700-400$ B.C.) [1]. In the production of iron, easily melted meadow ores coming from the open trench tunnel were used. The beginning of the $13^{\text {th }}$ century is a period of changes: primitive smeltering furnaces had been replaced by reusable kilns, as well minors were separated from blacksmiths. The iron ores were extracted in the area of Bytom, Myslowice, Gliwice and Toszek [10]. In 1796 a coking plant was opened in Gliwice, the first in Europe. Extraction of the iron ores in the nine coal mines of this region, amounted to approximately 800 thousand tons in the year of 1889 . This number decreased to about 140 thousand tons in 1913. It was still decreasing systematically over the next years. It was mainly due to low content of ores and depletion of natural resources.

- Hard coal - the Silesian region is most abundant in coal in all of Poland and Europe. One of the first mentions of this material being used comes from 1542. It was used in the blacksmith's shop of Jan Gierałtowski, owner of Biskupice and Ruda [11]. Extraction of coal is dated for the beginning of the $18^{\text {th }}$ century, and plays a great role of 
importance in the economy. Despite a large amount of coal and lumber in the area, along with superstitions about harmful effects of coal, lumber was most often used for heating purposes. However, there are many documents certifying that coal was used before the $18^{\text {th }}$ century in the Upper Silesia region [6]. Since 1740, the amount of income from the sell of hard coal appeared annually in the financial reports.

The remains of the plants concerning extraction and processing of these natural resources with an accompanying infrastructure comprises for the industrial heritage of the region. The industrial growth led to an infrastructure development such as: new roads, railways and railway stations in order to meet the needs of the developing transport of the natural resources, and ready made products - new roads, railways and railway stations. Tourism of industrial sites can be divided into different categories such as: mining tourism, metallurgy, railway tourism, etc. Silesian province is an area where anthropogenic assets dominate (for example, monuments of technology). They are located separately but they are joined by a road network. The monuments are on a straight line, and can be defined as a route [2]. The route is almost always a touristic product. It is usually marked out and its historical sites are accompanied by various touristic infrastructure located on the route [7].

The Government of the Silesia Province created four routs to protect the post-industrial remains:

- The Route of the Beginning of Metallurgy ( 22-kilometre route, running through Rybnik - Szczejkowice - Żory ). Some touristic attractions of the route are ruins of Waleska ironwork, and the Gichta Tower. It is the oldest touristic route of the Rybnik area, marked out in the 60-s of the $20^{\text {th }}$ century. The route runs through the extraction areas of the meadow ores used in the process of iron melting in so called blacksmiths' shops.

- The Route of the History of Mining ( about 100- kilometre long, that runs through the cities like: Siemonia, Bobrowniki, Siemianowice Śląskie, Katowice, Mikołów, Orzesze, Rybnik). The main attractions are numerous sites connected with the history of mining and metallurgy in these locations.

- The Route of Patronackie Districts (workers estates, settlements). They were built by the owners of the ironworks and coal mines for employees, so that they lived closely to where they worked. Its construction history originates from the $18^{\text {th }}$ century. One of the oldest of these types of housing estates in the Silesia region is a workers' housing estate in Chorzów on Kalidego Street, erected in 1798 for employees of Królewska Huta. Brick houses were the basis of this type of building. One of the most popular workers' housing estate is Nikiszowiec.

- Industrial Monuments Route - the most popular route which in January 2010, was the only one from the Middle and Eastern Europe registered with the ERIH ( European Route of Industrial Heritage) [12]. Moreover, in the same year it was awarded with the Gold Medal of the Poznan Fair for the best touristic product in Poland.

Without doubt, together with Industrial Monuments Route connected with touristic values makes it possible to pursue different forms of tourism. It is related with apprise of intangible assets including elements of material culture [7].

The above mentioned intangible assets, promote the development of educational tourism also called a tourism of passions [3]. Undoubtedly, the biggest advantage of the region is a possibility of learning about historical monuments located on the routes with the 
most developed public transportation (20\% of all roads in Poland) is of great importance. Silesian province has 1373 kilometres of railways networks. There are 362 kilometres of tram tracks. Moreover, the International Airport in Pyrzowice makes for a fast access to the tourist region visitors coming from other countries.

As it was mentioned earlier the most popular route is the Industrial Monuments Route. Annually, "Industriada" takes place which is a festival promoting Industrial Monuments Route. In 2011, 54 thousand of participants took part in many ceremonies related with this festival. In 2012, the Festival of Industrial Monuments Route was awarded the most prestigious advertising competition in Poland, "KREATURA". "Industriada" was distinguished in the category of "event/ambient". In 2012, the festival will take place in the Industrial Area of Rhury and Donetsk, two other industrial centres in Europe.

Industrial Monuments Route as a regional offer:

- shows traditional culture of the region, and gives the visitors more opportunities to become more acquainted with the culture;

- it is based on products and regional benefits that can be more easily distinguished and identified;

- it not only includes the history of the region and its tradition, but also its current situation, changes and its character;

- helps to maintain and use unique world wide sites [13].

At the present, the route includes 36 historic sites ( their location in the province is shown by picture 1 ). They are:

1) Museum of the Production of Matches - Częstochowa,

2) Museum of Railway History - Częstochowa,

3) Museum of Mining Iron Ores - Częstochowa,

4) Glasswork "Zawiercie" - Zawiercie,

5) Training Coal Mine by the „Sztygarka” Municipal Museum - Dąbrowa Górnicza,

6) The Black Trout Gallery - Tarnowskie Góry,

7) Historic Silver of Mine - Tarnowskie Góry,

8) Historic Water Station - „Zawada” - Karchowice,

9) Museum of Bread, School and News - Radzionków,

10) Upper Silesian Narrow Gauge Railways - Bytom,

11) Power Plant "Szombierki" - Bytom,

12) Gallery of Contemporary Art - "Power Station Plant - Czeladź",

13) Railway Station PKP - Sosnowiec,

14) Central Museum of Fire - Mysłowice,

15) Gallery "Shaft" Wilson - Katowice,

16) Nikiszowiec Housing Estate - Katowice,

17) Giszowiec Housing Estate - Katowice,

18) The Extracting Tower "President" Shaft with "Sztygarka" complex - Chorzów,

19) Colonial Workers "Ficinus" - Ruda Śląska,

20) Museum of Coal Mining - Zabrze,

21) Mining Open Air Museum "Luiza Queen" - Zabrze,

22) Maciej "Shaft" - Zabrze,

23) Historical Anthracite Mine "Guido" - Zabrze, 
24) Radio Tower - Gliwice,

25) Museum of Sanitary Technology - Gliwice,

26) Museum of Artistic Casting Department- Gliwice,

27) Historical Station of the Narrow Gauge Railways - Ruda,

28) Historical Mine "Ignacy" - Rybnik,

29) Museum of Power Industry - Łaziska Górne,

30) Tyskie Brewery Museum - Tychy,

31) Museum of the Silesian Press by Wojciech Korfanty - Pszczyna,

32) Museum of Technology and Textile Industry - Bielsko - Biała,

33) The Bus Station PKP - Bielsko-Biała,

34) Museum of Printing - Cieszyn,

35) Ustrońskie Museum by Jan Jarecki - Ustroń,

36) Brewery and Brewing Museum Żywiec - Żywiec.

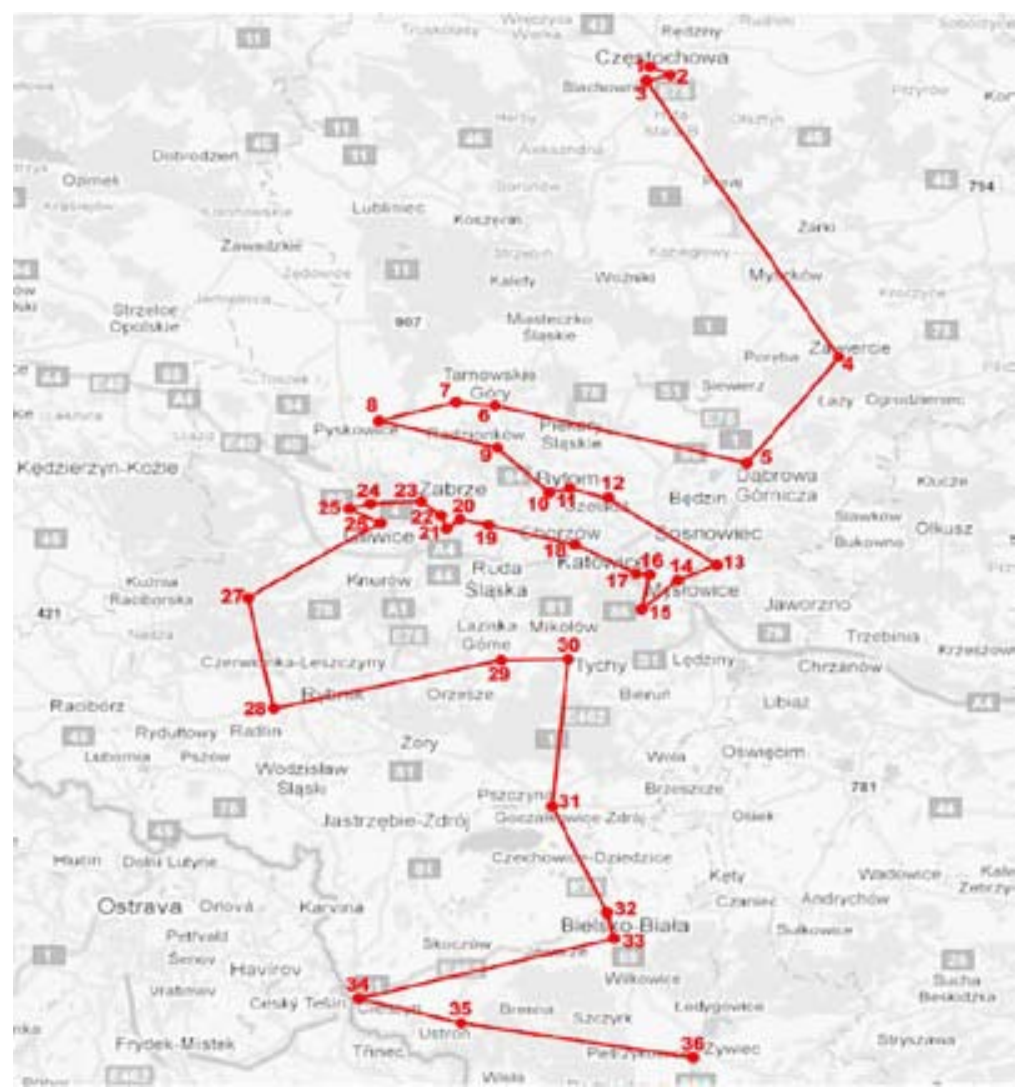

Picture 1

Industrial Monuments Route of the Silesia Province

Źródło: Opracowanie własne oraz www.maps.google.pl umieszczone wcześniej w A. Kaczmarska, A. Przybyłka: Wykorzystanie potencjału przemystowego i poprzemystowego na potrzeby turystyki. Przykład Szlaku Zabytków Techniki województwa śląskiego. Krajobraz a turystyka 2010, nr 14, s. 213. 
The highest number of post-industrial historical sites being included to the Industrial Monuments Route can be found in Zabrze, Częstochowa, Katowice and Gliwice. Among all these unique monuments with undisputable historical value connected with industrial heritage of the region, can be listed: the Radio Tower in Gliwice and a complex including the industrial sites in Zabrze, connected with coal mining. According to experts these two mentioned industrial sites have the highest chances to be included on the List of the World Cultural and Natural Heritage UNESCO. Additionally, that would strengthen the touristic value of the region. Since the beginning of existence of the Industrial Monuments Route, a considerable part of activity was directed on the promotion of this product. The following elements are used in its marketing communication:

- visual identification system ( with its logo ),

- pecial internet profile,

- system of indication of the sites being included to the route, which are: road signs, information board, plates - the certificates of belonging, visiting cards, publishing agencies [14].

Promotion of the historic industrial sites should take place not only in Poland but also abroad. All of these products are often unique, and they can attract tourists from abroad.

Taking advantage of the rich heritage as a certificate of history and material culture of the region from the past and the modern ones, it may be perceived as an attractive product with a significant potential of development as a rich offer "tourism of industrial heritage", for present and the future generations. During a visit in these industrial historical monuments you can hear roar of engines, clatter of machines, feel the smell of wood, feel the cool air of underground, touch the metal, etc. In the result the visitor has not only the chance to learn about the industrial heritage of the region, but also he can touch, feel or taste its original tradition. Thanks to these exceptional experiences you can convince yourself that the historical monuments of technology is a place where in an interesting way you can spend free time [15].

It is possible that the Industrial Monuments Route will become one of the main landmarks of Silesia and will characterize this region on the touristic map of Poland and Europe. However, to happen this it must meet some requirements. Touristic trade mark should possess defined set of qualities to which we can include:

- authenticity - connected with environment and cultural values existing in the particular area,

- attractiveness - connected with natural, material, social and cultural values of the particular region,

- uniqueness - connected with unusual conception, its originality,

- guarantee - connected with a high quality of the product,

- complexity - connected with offering package and touristic offers

- recognition - connected with possessing of mark as well as successfully leading marketing,

- coherence - connected with compatibility of the product with developing programs of strategy in the range of regional politics,

- openness - connected with cordial and friendly acceptance of tourists,

- availability - connected with adjustment of the product to individual needs of tourists, 
- flexibility - connected with the opportunity of taking advantage of the product and introducing corrections while using it [7].

Meeting all these requirements can lead to creating a new regional image that could take advantage of its industrial heritage as a trump card to its new aims. All these qualities such as: authenticity, originality, incomparability, uniqueness, attractiveness have already been fulfilled by the route.

Taking into account the main advantages for the region, first of all we can show financial benefits connected with the inflows to the local budgets, gaining profits by the entrepreneurs, the development of entrepreneurship, increasing turnover and services. Taking advantage of industrial heritage causes increase in a social activities, creating job opportunities, prevention of social exclusion, increasing living standards, integrating local societies, shaping social relationship. Moreover, it has also got an educational value ( passing on history of the region to a young generation in an interesting and simple way ), and touristic value because thanks to this is created a unique offer.

Industrial tourism has chances of becoming region's landmark.

\section{LIST OF REFERENCES}

1. Czapliński M., E. Kaszuba, G. Wąs, R. Żerelik: Historia Śląska. UW, Wrocław 2007, s. 28-29.

2. Gołembowski G.: Produkt turystyczny: szansa $i$ wyzwanie. W: Promocja i kreowanie turystycznego wizerunku Polski. POT, Warszawa 2005, s. 58.

3. Kazimierczak M.: Wytyczne komercjalizacji kultury w obszarze turystyki kulturowej. W: Gospodarka turystyczna w XXI wieku. Zeszyty Naukowe WSHiU w Poznaniu nr 19, Poznań 2010, s. 59.

4. Kudetko J., A. Juzyk, A. Szczerbiak: Uwarunkowania determinujące strategię ochrony i udostępniania reliktów dziedzictwa przemysłowego. W: Dzieje górnictwa - elementy europejskiego dziedzictwa kultury. Pod red. P. Zagwożdżona i M. Madziarza, Tom 2, UW, Wrocław 2009, s. 118.

5. Naziębiło J.: Dziedzictwo przemysłowe Żyrardowa a możliwości zagospodarowania turystycznego. W: Dziedzictwo przemysłowe Mazowsza i jego rola w turystyce. Pod red. F. Kaprowski, J. Midura i J. W. Sienkiewicz, WSE, Warszawa 2008, s. 215.

6. Por.: „Wirtchaftsberichte” w aktach korespondecji regentów z panem stanowym z 1657 roku oraz rachunki z XVII wieku. E. Zivier: Entwicklung des Steinkohlenbergbaues im Fürstentum Pless. Kattowitz 1913 - baron von Stechow pisze w odpowiedzi na zapytanie Urzędu Górniczego, iż wydobycie węgla na jego terenach było prowadzone od niepamiętnych lat.

7. Szczepanowski A. E.: Markowe produkty turystyczne. PWE, Warszawa 2012, s. 22.

8. Turystyka w obiektach poprzemysłowych. POT, Warszawa 2004, s. 6.

9. Ustawa o ochronie zabytków i opiece nad zabytkami: Art. 6 (Dz. U. 2003, nr 162, poz. 1568)

10. Zaleski W.: Dzieje górnictwa i hutnictwa na Górnym Śląsku do roku 1866. Antonina Zaleska, Madryt 1967, s. 6 i nast.

11. Ziemba J.: Stromą na dół drabiną. Z tradycji polskiego górnictwa. Śląski Instytut Naukowy, Katowice 1983, s. 39.

12. http://www.erih.net 
13. http://zabytkitechniki.pl

14.http://zabytkitechniki.pl/pl/t/SZT_Dzialania_promocyjne_Szlaku

$15 \mathrm{http}: / /$ zabytkitechniki.pl/pl/t/SZT_Opis_szlaku

Стаття: надійшла до редколегї 28.05.2012

прийнята до друку 06.06.2012

\title{
ВИКОРИСТАННЯ ПРОМИСЛОВОГО СПАДЩИНИ У СФЕРІ ТУРИЗМУ В СІЛЕЗІї
}

\author{
А. Пшибилка \\ Департамент соиіальної та економічної політики \\ Університет економіки в м. Катовіщее, Польща
}

\begin{abstract}
На сьогоднішній день, Сілезія як і раніше асоціюється з промисловим регіоном. Тим не менш, в останні роки, велика частина заводів зупинила або скоротила виробництво своєї продукції. Видобуток кам'яного вугілля, яка досі є символом регіону, постійно знижується. Крім цього, є багато промислових об'єктів, які протягом багатьох років вже не виконують своїх колишніх функцій. У зв'язку з цим, з'явилася можливість використовувати індустріальне спадщина в сфері туризму промислового. Дане використання промишленних ресурсів підвищує привабливість регіону і дозволяє на його використання та охорону, а не повільну амортізаціію цих об'єктів. дана статті представляє як в даний час індустріальне спадщина використовується для розвитку і реклами Сілезії.
\end{abstract}

Ключові слова: промислова спадщина, індустріальний туризм, технологічні пам'ятники

\section{ИСПОЛЬЗОВАНИЕ ПРОМЫШЛЕННОГО НАСЛЕДИЯ В СФЕРЕ ТУРИЗМА В СИЛЕЗИИ}

\author{
А. Пшибылка \\ Департамент социальной и экономической политики \\ Университет экономики в г. Катовице, Польша
}

На сегодняшний день, Силезия по-прежнему ассоциируется с промышленным регионом. Тем не менее, в последние годы, большая часть заводов остановила или сократила производство своей продукции. Добыча каменного угля, которая до сих пор является символом региона, постоянно снижается. Кроме этого, есть много промышленных объектов, которые в течение многих лет уже не выполняют своих прежних функций. В связи с этим, появилась возможность использовать индустриальное наследие в сфере туризма промышленного. Данное использование промышленных ресурсов повышает привлекательность региона и позволяет на его использование и охрану, а не медленную амортизациию этих объектов. данная статье представляет как в настоящее время индустриальное наследие используется для развития и рекламы Силезии.

Ключевые слова: промышленное наследие, индустриальный туризм, технологические памятники. 